\title{
Status Kandungan Logam Berat Perairan Pesisir Kabupaten Aceh Utara dan Kota Lhokseumawe
}

\section{The State of Heavy Metal Content in the Coastal Water of Aceh Utara Regency and Lhokseumawe City}

\author{
WAGE KOMARAWIDJAJA ${ }^{1 *}$, AGUNG RIYADI ${ }^{1}$ DAN YUDHI SOETRISNO GARNO ${ }^{1}$ \\ Pusat Teknologi Lingkungan -Badan Pengkajian dan Penerapan Teknologi \\ Gedung Geostech 820, Puspiptek Serpong 15314, Indonesia \\ wage.komarawidjaja@bppt.go.id
}

\begin{abstract}
The coastal area of Lhokseumawe City - Aceh Utara Regency is one of the economic growth centers in the Special Province of Aceh Province, which has been designated a special economic zone (KEK), and in it will operate new industries. With the operation of these industries then in the future the coastal waters of Lhoksemawe-Aceh will be the final destination of various waste from the industry in Lhokseumawe $K E K$ which contains heavy metals. In order to find out the increase in heavy metal concentration in the future, concentaration of heavy metal information is needed today. For this reason, the research is conducted with the aim to know the heavy metal concentration, such as mercury ( $\mathrm{Hg})$, Cadmium (Cd), Copper $(\mathrm{Cu})$, Lead $(\mathrm{Pb})$ and Zinc $(\mathrm{Zn})$. This study revealed that except Lead $(\mathrm{Pb})$, the heavy metal concentration observed in the waters of Louksemawe-Aceh Utara is still below the threshold of standard quality applicable in Indonesia. With regard to the quality of waters that tend to deteriorate, then waste treatment in every industry operating in SEZ needs to be done well.
\end{abstract}

Keywords: coastal zone, special economic zone, coastal waters, heavy metals

\begin{abstract}
ABSTRAK
Kawasan pesisir Kota Lhokseumawe-Kabupaten Aceh Utara merupakan salah satu pusat pertumbuhan ekonomi di Provinsi Daerah Khusus Aceh, yang telah ditetapkan menjadi kawasan ekonomi khusus (KEK), dan didalamnya akan beroperasi industri-industri baru. Dengan beroperasinya industri-industri tersebut maka dimasa yang akan datang perairan pesisir Lhoksemawe-Aceh akan menjadi tujuan akhir dari berbagai limbah dari industri di KEK Lhokseumawe yang diantaranya mengandung logam berat. Dalam rangka mengetahui peningkatan konsentrasi logam berat dimasa mendatang diperlukan informasi kadungan logam berat saat ini. Untuk itulah maka penelitian ini dilakukan dengan tujuan untuk mengetahui konsentrasi logam berat, seperti Air raksa $(\mathrm{Hg})$, Cadmium $(\mathrm{Cd})$, Tembaga $(\mathrm{Cu})$, Timbal $(\mathrm{Pb})$ dan Seng $(\mathrm{Zn})$. Penelitian ini mengungkapkan bahwa selain Timbal $(\mathrm{Pb})$, konsentrasi logam berat yang diteliti di perairan Louksemawe-Aceh Utara masih berada dibawah ambang batas baku mutu yang berlaku di wilayah Indonesia. Berkenaan dengan kualitas perairan yang cenderung memburuk tersebut, maka pengolahan limbah di setiap industri yang beroperasi di dalam KEK Lhokseumawe perlu dilakukan dengan baik.
\end{abstract}

Kata kunci : Kawasan Pesisir, Kawasan Ekonomi Khusus, Perairan pesisir, logam berat

\section{PENDAHULUAN}

\subsection{Latar Belakang}

Pusat pertumbuhan ekonomi di pesisir utara Aceh tepatnya di Kota Lhoksemauwe dan Kabupaten Aceh Utara, telah berjalan selama 35 tahun yang dimotori oleh PT Arun LNG dan ditunjang oleh industri turunannya yaitu industri Pupuk Iskandar Muda (PT. PIM) serta PT Asean Aceh Fertilizer (PT. AAF). Perkembangn tersebut, kini terancam berhenti, karena sejak tahun 2014, PT. Arun LNG tidak dapat lagi menghasilkan gas sebagai sumber energy dan sumber bahan baku industry turunannya.

Guna mempertahankan keberlanjutan pembangunan ekonomi wilayah ini dan sekaligus menyelamatkan aset yang bernilai tinggi, pemerintah memutuskan untuk merevitalisasi kawasan industry PT. Arun LNG menjadi Kawasan Ekonomi khusus (KEK) Arun Lhokseumawe $^{(1)}$. KEK ini dibentuk untuk membuat lingkungan lebih kondusif bagi aktivitas iklim investasi, ekspor, perdagangan, meningkatkan keunggulan bersaing komoditas 
ekspor, meningkatkan pemanfaatan sumberdaya lokal, pelayanan dan kapital serta mendorong peningkatan kualitas SDM melalui transfer teknologi. Dengan kata lain, pembangunan KEK secara umum diharapkan mampu mengundang investor meningkatkan nilai investasinya ${ }^{(2)}$.

KEK yang berada di pesisir utara Provinsi Aceh ini, secara administrasi melibatkan 3 kecamatan yaitu Kecamatan Dewantara di Kabupaten Aceh Utara dengan luas areal $722 \mathrm{Ha}$ dan Banda Baru serta Kecamatan Muara Satu di Kota Lhokseumawe dengan luas areal $2128 \mathrm{Ha}$. Di Wilayah KEK tersebut akan dikembangkan sebagai kawasan Industri migas, agro industri, serta industri Logistik seperti perdaganganekspor/impor, packaging, pergudangan dan sektor komersil lainnya.

Sementara, secara geografis, wilayah KEK Arun Lhokseumawe berbatasan langsung dengan perairan selat Malaka; menelusuri garis pantai sepanjang 12 kilometer. Ini memperlihatkan bahwa sebagian besar wilayah KEK Arun Lhokseumawe merupakan wilayah pesisir. Perairan pesisir ini, tanpa bisa dihindari akan menjadi tujuan akhir dari berbagai limbah cair dari industri dan pemukiman yang ada di sekitar KEK Arun Lhokseumawe.

Limbah cair buangan dari industri dan pemukiman, jika diolah dengan hasil sesuai baku mutu yang berlaku mungkin tidak akan menjadi masalah serius, namun terkadang baku mutu memilki konsentrasi yang lebih besar daripada konsentrasi parameter-parameter eksisting perairan, maka masuknya limbah tersebut lambat laun akan merubah kualitas perairan pesisir kearah kualitas yang tidak dikehendaki seperti terjadinya pencemaran logam berat. Ini bisa terjadi karena makin tinggi limbah yang mengandung logam masuk ke suatu perairan makin tinggi pula konsentrasi logam beratnya. ${ }^{(3)}$ Oleh karena itu, Perubahan logam berat dalam perairan perlu diketahui karena logam berat dapat menimbulkan berbagai macam gangguan kesehatan dan penyakit bagi manusia, seperti tragedi "Minamata dan itai-itai" di Jepang yang disebabkan oleh air raksa dan kadmium nampaknya tak akan pernah dilupakan orang.

Beberapa logam berat dalam jumlah yang kecil diperlukan untuk hidup, sebagai elemen mikro (mikronutrien) seperti besi, tembaga dan seng. Logam berat yang lain seperti air raksa dan kadmium, meskipun belum diketahui perannya dalam metabolisme namun beracun bagi manusia, binatang dan tanaman ${ }^{(3)}$ Oleh karenanya sebutan "logam berat" biasanya diperuntukan bagi logam -logam yang beracun; termasuk didalamnya adalah unsur-unsur timbal $(\mathrm{Pb})$, kadmium $(\mathrm{Cd})$, tembaga $(\mathrm{Cu})$, selenium (Se), arsen (As), air raksa $(\mathrm{Hg})$, dan kromium $(\mathrm{Cr})$.
Logam berat, di alam ditemukan dalam jumlah yang kecil dan umumnya ditemukan dalam bentuk senyawa dengan sulfida atau kompleks mineral yang terdiri dari oksigen, silika dan sulfur. Selain itu logam berat ditemukan sebagai hasil sampingan dari kegiatan penambangan, seperti $\mathrm{Cd}$ yang ditemukan pada proses pencairan seng $\left({ }^{2}\right.$.

Logam-logam berat yang berbahaya bagi kehidupan tersebut memiliki berbagai sumber yang dapat masuk ke badan air. Berbagai macam buangan air diketahui mengandung senyawa logam berat dan buangan semacam ini sering dibuang ke selokan umum dengan tanpa melalui pengolahan. Pustaka yang ada mengungkapkan bahwa makin tinggi limbah yang mengandung logam masuk ke suatu perairan makin tinggi pula konsentrasi logam beratnya ${ }^{(4)}$.

Dalam rangka mengantisipasi perubahanperubahan logam berat yang telah terjadi selama ini dan dimasa mendatang diperlukan pengukuran kandungan logam berat di perairan Pesisir wilayah perbatasan kabupaten Aceh Utara dan Kota Lhokseumawe yang telah mengalami kemajuan cukup pesat dalam pembangunan, khususnya beberapa logam berat yang diketahui membahayakan kesehatan manusia, yakni Air raksa $(\mathrm{Hg})$, Cadmium (Cd), Tembaga (Cu), Timbal $(\mathrm{Pb})$ dan Seng (Zn).

\subsection{Tujuan}

Penelitian ini bertujuan untuk mengetahui status konsentrasi beberapa logam berat di Pesisir wilayah perbatasan kabupaten Aceh Utara dan Kota Lhokseumawe, berdasarkan bakumutu air laut, Kepmen-LH 51 Tahun 2004.

\section{BAHAN DAN METODE}

\subsection{Tempat dan Waktu Penelitian}

Penelitian ini dilakukan di perairan pesisir Kota Lhokseumawe-Kabupaten Aceh Utara dengan mengambil contoh air di 3 titik sampling yang masing-masing disebut TPS-1 yang tepatnya di Kuala Ujong Blang pada posisi lintang N $05^{\circ} 12^{\prime}$ 54"; E 097 06' 58,3"; TPS-2 yang tepatnya di PT. Arun pada posisi lintang $\mathrm{N}$ $05^{\circ} 13^{\prime}$ 58,0"; E $097^{\circ} 05^{\prime} 08,6^{\prime \prime}$; TPS-3 dan TPS4 yang tepaqtnya di Muara Kr. Geukeuh pada posisi lintang N $05^{\circ} 14^{\prime} 30,7$; E $097^{\circ} 02^{\prime}$ 49,6”. Dan TPS-4 yang tepatnya di Mulut Pelabuhan PIM pada posisi lintang $\mathrm{N} 05^{\circ} 15^{\prime} 00,1$; E $097^{\circ}$ 01 ' 58,5" Pengambilan contoh air (penelitian) dilakukan pada Bulan Juli 2016. 


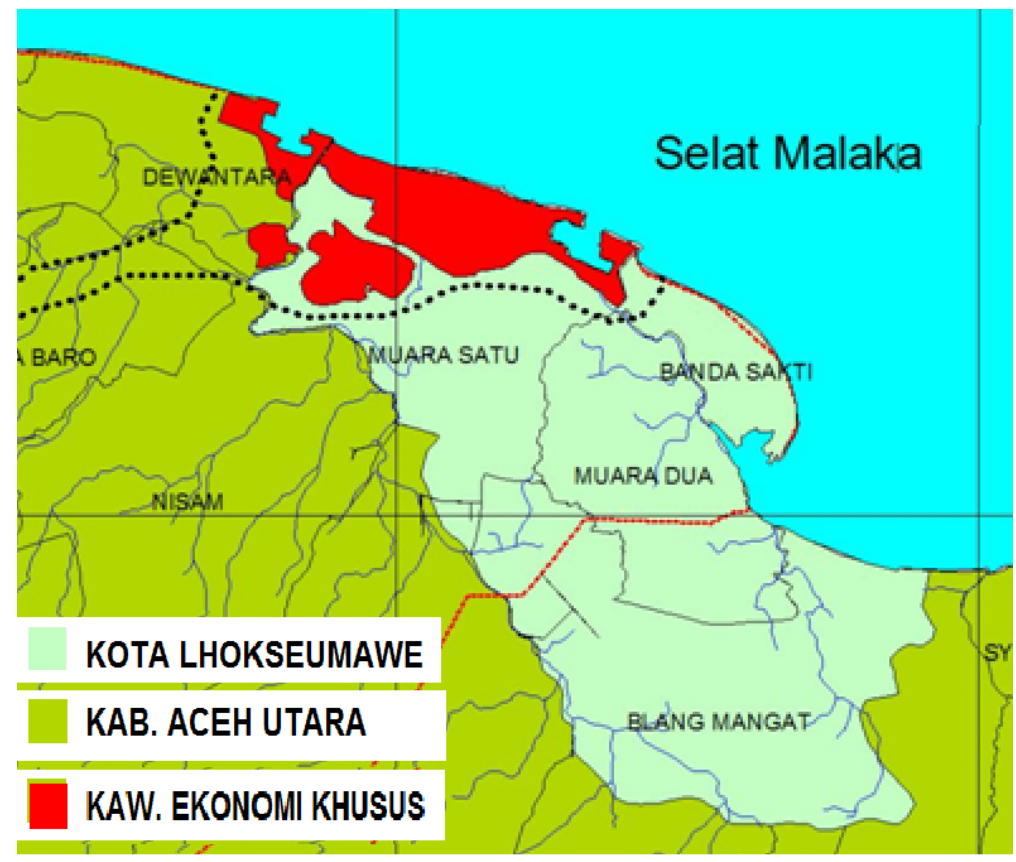

Gambar 1. Tempat pengambilan sampel air

Tabel-1. Daftar alat dan metode yang digunakan untuk menganalisa sampel.

\begin{tabular}{ccc}
\hline Parameter (Units) & Methoda & Remarks \\
\hline $\begin{array}{c}\text { Suhu air }\left({ }^{\circ} \mathrm{C}\right) \\
\text { Salinitas }(\mathrm{NTU})\end{array}$ & Electrometri & In-situ, SCT-meter \\
$\mathrm{pH}$ & Nephlometric & In-situ, SCT-meter \\
$\begin{array}{c}\text { Logam berat } \mathrm{Hg}, \mathrm{Cd}, \\
\mathrm{Cu}, \mathrm{Pb} \text {, dan } \mathrm{Zn}(\mathrm{mg} / \mathrm{l})\end{array}$ & AAS & - \\
\hline
\end{tabular}

Sumber: ${ }^{(5)}$

\subsection{Analisa sampel}

Di Laboratorium Dinas Lingkungan Hidup, Propinsi Aceh, sampel-sampel yang telah dikumpulkan dianalisa dengan metode dan peralatan sebagai tersebut pada Tabel- $1^{(5)}$

\section{HASIL DAN PEMBAHASAN.}

Seperti telah disebutkan diatas, penelitian ini dilakukan dengan mengambil air contoh di 4 (empat) titik pengambilan sampel (TPS). Hasil pengukuran dan analisis sampel-sampel tersebut disajikan pada tabel-2

\subsection{Fisik dan Kimia}

Temperatur air di keempat stasiun/TPS (Tabel-2) di perairan pesisir Kota Lhokseumawe -Kabupaten Aceh Utara berfluktuasi antara $30,4-30,5{ }^{\circ} \mathrm{C}$. Temperatur ini lebih rendah dari hasil pengukuran pada Mei $2015^{(6)}$. yang berkisar antara $30-32{ }^{\circ} \mathrm{C}$. lebih tinggi dari hasil pengukuran pada
Februari $2016^{(7)}$. yang berkisar antara 28-29 ${ }^{\circ} \mathrm{C}$. Perbedaaan tersebut diduga terjadi karena adanya perbedaan waktu pengukuran, dan kisaran suhu tersebut adalah kisaran yang normal bagi perairan di sekitar daerah tropis. Fenomena ini mengisaratkan bahwa perairan pesisir Lhokseumawe-Aceh Utara belum dicemari oleh limbah yang panas.

Perairan pesisir Lhokseumawe-Aceh pada waktu yang sama memiliki Kadar garam (salinitas) antara 25,8-27,4. Nilai terkecil diperoleh di TPS- yang berada di Muara Kr. Geukeuh yang mendapatkan pengenceran air sungai yang masuk kemuara tersebut. Nilai kajian ini lebih rendah dari hasil pengukuran pada Mei $2015^{(6)}$. yang berkisar antara 32,734,1 dan Februari $2016^{(7)}$ yang berkisar antara 32,3-34,3. Kisaran-kisaran tersebut adalah nilai yang alamiah, oleh karenanya tidak akan mempengaruhi kehidupan didalamnya. 
Tabel 2. Konsentrasi logam berat di perairan pesisir Kota Lhokseumawe-Kabupaten Aceh Utara pada bulan Juli 2016.

\begin{tabular}{lccccccc}
\hline \multirow{2}{*}{ No Parameter } & Satuan & \multicolumn{3}{c}{ Tempat Pengambilan Sampel/TPS } & \multicolumn{2}{c}{ Baku Mutu* } \\
& & L-1 & L-2 & L-3 & L-4 & Pelabuhan & Biota \\
\hline Fisik & & & & & & & \\
Temperatur & ${ }^{\circ} \mathrm{C}$ & 30,4 & 30,5 & 30,4 & 30,4 & Alami & Alami \\
TSS & $\mathrm{mg} / \mathrm{L}$ & 32 & 40 & 27 & 39 & 80 & 20 \\
Kimia & & & & & & & \\
pH & & 7,8 & 7,7 & 7,7 & 7,6 & $6,8-8,5$ & $6,8-8,5$ \\
Salinitas & $0 / 00$ & 27 & 27,4 & 25,8 & 26,8 & natural & natural \\
Logam Berat & & & & & & & \\
Air raksa $(\mathrm{Hg})$ & $\mathrm{mg} / \mathrm{L}$ & $<0,00019$ & $<0,00019$ & $<0,00019$ & $<0,00019$ & 0,003 & 0,001 \\
Cadmium $(\mathrm{Cd})$ & $\mathrm{mg} / \mathrm{L}$ & $<0,005$ & $<0,005$ & $<0,005$ & $<0,005$ & 0,01 & 0,001 \\
Tembaga $(\mathrm{Cu})$ & $\mathrm{mg} / \mathrm{L}$ & $<0,008$ & $<0,008$ & $<0,008$ & $<0,008$ & 0,05 & 0,008 \\
Timbal $(\mathrm{Pb})$ & $\mathrm{mg} / \mathrm{L}$ & $<0,05$ & 0,10 & 0,70 & $<0,05$ & 0,05 & 0,008 \\
Seng $(\mathrm{Zn})$ & $\mathrm{mg} / \mathrm{L}$ & $<0,04$ & $<0,04$ & $<0,04$ & $<0,04$ & 0,1 & 0,05 \\
\hline
\end{tabular}

Keterangan:

Baku Mutu : Kepmen-LH 51 Tahun 2004 tentang Baku Mutu Air Laut. pada lampiran I untuk Pelabuhan dan Lampiran III untuk kehidupan Biota Laut

Sumber data Primer hasiil sampling Juli 2016

L-1 : Kuala Ujong Blang N $05^{\circ} 12^{\prime} 54^{\prime \prime} ;$ E $097^{\circ} 06^{\prime} 58,3^{\prime \prime}$

L-2 : PT. Arun N $05^{\circ} 13^{\prime} 58,0^{\prime \prime} ;$ E $097^{\circ} 05^{\prime} 08,6^{\prime \prime}$

L-3 : Muara Kr. Geukeuh N $05^{\circ} 14^{\prime} 30,7$; E $097^{\circ} 02^{\prime} 49,6^{\prime \prime}$

L-4 : Mulut Pelab. PIM N 05 15'00,1; E $097^{\circ} 01^{\prime}$ 58,5”

Pada saat yang sama, perairan memiliki nilai $\mathrm{pH}$ yang berkisar antara 7,6-7,8. Perairan yang tidak tercemar pada umumnya memiliki $\mathrm{pH}$ antara 6.5-9.0. Ini berarti perairan pesisir Lhokseumawe-Aceh Utara yang berkisar antara $7,6-7,8$ masih tergolong normal. Demikian pula jika dibandingkan dengan ketentuan yang ada pada Kepmen-LH 51 Tahun 2004 tentang Baku Mutu Air Laut. Nilai pH tersebut masih memenuhi semua peruntukan air laut ${ }^{(8)}$

\subsection{Logam Berat}

Berdasarkan Keputusan Menteri Negara Lingkungan Hidup Nomor 51 Tahun 2004 Tentang Baku Mutu Air Laut; pemanfaatan perairan pesisir menurut peruntukannya digolongkan kedalam 3 kelompok yakni perairan pantai sebagai (a) perairan pelabuhan (b) kawasan wisata bahari dan (c) kawasan biota laut.

Pesisir Kota Lhokseumawe-Aceh Utara belum ditentukan peruntukannnya sehingga hasil kajian ini tidak ditujukan untuk membahas peruntukan tertentu. Penelitian ini tidak dilakukan pada semua unsur logam berat yang ada diperairan pesisisr Kota Lhokseumawe-Kab. Aceh Utara, namun hanya menghukur beberapa logam berat yang diketahui membahayakan kesehatan manusia, yakni Air raksa $(\mathrm{Hg})$,
Cadmium (Cd), Tembaga (Cu), Timbal $(\mathrm{Pb})$ dan Seng $(\mathrm{Zn})$.

Air raksa $(\mathrm{Hg})$ adalah logam berat berbahaya bagi kesehatan manusia, yang sudah dikenal sejak peristiwa di Minamata, Jepang tahun 1953. Tabel-2 menunjukkan bahwa pada saat sampling, konsentrasi Air raksa $(\mathrm{Hg}) \mathrm{di}$ setiap TPS pada saat penelitiaan dilakukan adalah sama yakni < 0,00019 mg/l. Nilai ini tergolong sangat rendah dan sama sekali tidak mengganggu biota perairan, termasuk ikan; yang telah ditentukan nilai ambang batasnya $0.001 \mathrm{mg} / \mathrm{l}^{[8]}$. Hasil ini lebih rendah jika dibandingkan dengan hasil pengukuran pada Mei $2015^{(6)}$. dan Februari2016. Perbedaan tersebut sulit diduga karena pengambilan sampel pada Mei $2015^{(6)}$ dan Februari 2016 dilakukan ditempat yang sedikit ke tengan, dan dilakukan dengan metode berbeda. Meskipun terdapat perbedaan besaran konsentrasi, namun nilai semua hasil pengukuran tersebut masih jauh dibawah baku mutu yang berlaku untuk peruntukan apapun sehingga perairan pesisir Kota Lhokseumawe- Kab. Aceh Utara aman untuk dijadikan tambak, pelabuhan ataupun wisata bahari. Selain masih jauh dari Baku mutu yang berlaku, $\mathrm{Hg}$ di perairan pesisir Kota Lhokseumawe- Kab. Aceh Utara ini juga 
masih jauh lebih kecil dari kandungan $\mathrm{Hg}$ yang terukur di pesisir Jakarta ${ }^{(9,10)}$

Kadmium (Cd) adalah unsur logam inorganik yang lunak berwarna putih kebirubiruan dan beracun. Keracunan kadmium ringan dapat mengakibatkan perut mual, muntahmuntah, diare, luka hati, shok dan gagal ginjal, sedangkan keracunan berat dapat mengakibatkan penyakit ginjal, liver, tulang rapuh dan kerusakan sel-sel darah. Tabel-2 menunjukkan bahwa pada saat sampling, konsentrasi Kadmium (Cd) di setiap TPS pada saat penelitiaan dilakukan adalah sama yakni < $0,005 \mathrm{mg} / \mathrm{l}$. Hasil ini lebih tinggi jika dibandingkan dengan hasil pengukuran pada Mei $2015^{(6)}$ dan Februari $2016^{(7)}$ Perbedaan tersebut sulit diduga karena pengambilan sampel pada Mei $2015^{(6)}$ dan Februari $2016^{(7)}$ dilakukan ditempat yang sedikit ke tengan, dan dilakukan dengan metode berbeda. Meskipun terdapat perbedaan besaran konsentrasi, namun nilai semua hasil pengukuran tersebut masih jauh dibawah baku mutu yang berlaku untuk peruntukan apapun sehingga perairan pesisir Kota Lhokseumawe- Kab. Aceh Utara aman untuk dijadikan tambak, pelabuhan ataupun wisata bahari. Seperti air raksa, cadmium di perairan pesisir Kota Lhokseumawe - Kab. Aceh Utara ini juga masih lebih kecil dari kandungan $\mathrm{Hg}$ yang terukur di pesisir Jakarta ${ }^{(9,10)}$.

Tembaga $(\mathrm{Cu})$ adalah komponen penting pada berbagai enzim. Logam ini merupakan nutrien penting yang dibutuhkan oleh badan dalam jumlah yang sangat kecil. Kelebihan tembaga akan dapat mengakibatkan penyakit perut dan usus, liver dan luka di ginjal, dan anemia. Secara umu cu akan lebih beracun pada biota perairan. Fitoplankton akan terganggu kehidupannya pada perairan dengan konsentrasi Cu sebesar 0,01 mg/l.

Sementara itu, crustasea akan mati dengan $\mathrm{Cu}$ pada kisaran konsentrasi 0.17-100 ppm, moluska akan mati pada kadar $\mathrm{Cu}$ antara 0.16$0.5 \mathrm{ppm}$, dan ikan-ikan akan mati kadar $\mathrm{Cu}$ sebesar 2.5-3.0 $\mathrm{ppm}^{(11) .}$

Secara umum konsentrasi tembaga di pesisir Kota Lhokseumawe-Kab. Aceh Utara pada saat sampling adalah sama di setiap TPS nya, yakni $<0,008 \mathrm{mg} / \mathrm{l}$. Konsentrasi ini lebih tinggi daripada hasil pengukuran Februari $2016^{(7)}$ namun lebih rendah daripada hasil pengukuran pada Mei 2015(6). Hasil pengukuran kajian ini dan Februari $2016^{(7)}$ meskipun ada perbedaan namun masih berada dibawah nilai baku mutu yang berlaku untuk semua peruntukan air laut. Yang perlu mendapat perhatian adalah bahwa hasil pengukuran Mei $2015^{(6)}$ pada Tabel-3 yang mencapai nilai maksimum $0,01 \mathrm{mg} / \mathrm{l}$ yang mengisaratkan bahwa saat itu perairan pesisir Kota Lhokseumawe-Kab. Aceh Utara tercemar oleh tembaga. Secara umum kandungan tembaga di pesisir Kota Lhokseumawe- Kab. Aceh Utara masih lebih rendah daripada kandungan tembaga di Cilincing yang dilaporkan mengandung timbel $0,002 \mathrm{mg} / /^{(9)}$.

Timbal $(\mathbf{P b})$ adalah logam organik yang berwarna putih kebiru-biruan, berat dan lunak tetapi inelastis. Kebanyakan timbal ditemukan dalam bentuk senyawa dengan unsur lain. Senyawa timbal diketahui memiliki daya racun yang kuat; dengan tingkat maksimum kontaminasi sekitar $0,015 \mathrm{ml} / \mathrm{l}$. Timbel dipercaya menjadi penyebab hipertensi, ketidak normalan reproduksi, dan syaraf.. Timbal banyak digunakan pada industri batere dan bahan tambahan pada gasoline. Selain itu timbel ditemukan juga pada imbah industri penambangan, pengecoran dan refaineri timbal, nikel, dan tembaga. Di perairan, timbal pada umumnya terakumulasi di dalam tubuh organisme perairan melalui rantai makanan.

Tabel-3 menunjukkan bahwa timbal $(\mathrm{Pb}) \mathrm{di}$ perairan pesisir Kota Lhokseumawe- Kab. Aceh Utara berkisar antara $<0,05-0,70 \mathrm{mg} / \mathrm{l}$, dengan nilai tertinggi ditemukan di TPS-3 yang berada di Muara Krueng Geukeuh. Nilai di TPS-3 yang $0,70 \mathrm{mg} / \mathrm{l}$ ini jauh lebih besar dari baku mutu yang berlaku untuk setiap peruntukan air pesisir. Demikian pula di TPS-2 yang $0,10 \mathrm{mg} / \mathrm{l}$. Ini mengisyaratkan bahwa perairan pesisir tercemar oleh timbal yang diduga berasal dari kegiatan di kawasan industry pesisir ini. Hasil pengukuran ini jauh lebih tinggi dari hasil pengukuran sebelumnya, dimana pada pada Mei $2015^{(6)}$ berkisar antara 0,005-0,05 mg/l sedangkan pada Februari $2016^{(7)}$ hanya berkisar antara 0,0004-0,0009 $\mathrm{mg} / \mathrm{l}$. Perbedaan yang menyolok tersebut diduga karena adanya pembuangan limbah dari daratan yang tidak sempurna pengolahannya.

Selain lebih tinggi dari pengukuran sebelumnya, hasil penelitian ini juga lebih tinggi daripada kadar timbal di teluk Jakarta yang hanya berkisar antara 0.001-0.0027 mg/(9). Kandungan $\mathrm{Pb}$ yang tinggi akan membahayakan kehidupan biota laut. Publikasi yang ada, mengungkapkan bahwa kandungan $\mathrm{Pb}$ sebesar $0.1-0.2 \mathrm{mg} / \mathrm{l}$ sudah menyebabkan keracunan pada beberapa jenis ikan ${ }^{(12)}$ dan pada kandungan $188 \mathrm{ppm}$ akan mematikan ikan ${ }^{(13)}$. 
Tabel 3. Perubahan konsentrasi logam berat di perairan pesisir Kota Lhokseumawe-Kabupaten Aceh Utara

\begin{tabular}{|c|c|c|c|c|c|c|c|c|c|}
\hline \multirow{3}{*}{ Parameter } & \multirow{3}{*}{ Unit } & \multicolumn{6}{|c|}{ Tempat pengambilan sampel (TPS) } & \multicolumn{2}{|c|}{ Baku mutu } \\
\hline & & \multicolumn{2}{|c|}{ Mei 2015} & \multicolumn{2}{|c|}{ Februari 2016} & \multicolumn{2}{|c|}{ Juli 2016} & PLB & BL \\
\hline & & maks & $\min$ & maks & Min & maks & Min & & \\
\hline Suhu air & $O C$ & 32,0 & 30,5 & 29,0 & 28,0 & 30,5 & 30,4 & alami & alami \\
\hline TSS & $\mathrm{mg} / \mathrm{l}$ & 98,0 & 0,5 & 34,0 & 29,0 & 40,0 & 27,0 & 80 & 20 \\
\hline Salinitas & $0 / 00$ & 3,41 & 3,27 & 34,3 & 32,3 & 27,4 & 25,8 & alami & alami \\
\hline $\mathrm{pH}$ & & 8,0 & 7,5 & 7,0 & 6,5 & 7,8 & 7,6 & $\begin{array}{l}6,8- \\
8,5\end{array}$ & $\begin{array}{l}6,8- \\
8,5\end{array}$ \\
\hline Air Raksa (Hg) & $\mathrm{mg} / \mathrm{l}$ & $<0,0005$ & $<0,0005$ & $<0,0005$ & $<0,0005$ & $<0,0002$ & $<0,0002$ & 0,003 & 0,001 \\
\hline Kadmium (Cd) & $\mathrm{mg} / \mathrm{l}$ & $<0,005$ & $<0,002$ & 0,0003 & 0,0002 & $<0,005$ & $<0,005$ & 0,01 & 0,001 \\
\hline Tembaga (Cu) & $\mathrm{mg} / \mathrm{l}$ & $<0,01$ & $<0,001$ & 0,0038 & 0,0019 & $<0,008$ & $<0,008$ & 0,05 & 0,008 \\
\hline Timbal (Pb) & $\mathrm{mg} / \mathrm{l}$ & 0,05 & 0,005 & 0,0009 & 0,0004 & 0,70 & $<0,05$ & 0,05 & 0,008 \\
\hline Seng (Zn) & $\mathrm{mg} / \mathrm{l}$ & $<0,02$ & $<0,02$ & $<0,0197$ & 0,0083 & $<0,04$ & $<0,04$ & 0,1 & 0,05 \\
\hline
\end{tabular}

Keterangan : Sumber data Laporan Audit PT Arun May 2015 dan Februari 2016.

Baku Mutu : Kepmen-LH 51 Tahun 2004 tentang Baku Mutu Air Laut. pada lampiran I untuk Pelabuhan (PLB) dan Lampiran III untuk kehidupan Biota Laut (BL).

Kecenderungan meningkatnya kadar $\mathrm{Pb}$ juga terdeteksi di perairan pesisir timur Sumatera Utara. Diungkapkan bahwa tingginya kadar logam berat timbal di perairan pesisir timur Sumatera Utara diduga disebabkan oleh limbah industri dan limbah lainnya yang mengandung logam berat yang masuk ke perairan pesisir melalui aliran sungai. Seperti di daerah Belawan yang merupakan pusat industri, perdagangan dan pelabuhan Kota Medan, merupakan perairan pesisir tempat penampungan berbagai jenis limbah yang terbawa melalui aliran Sungai Deli.

Hal yang sama terjadi di kota Tanjung Balai, yang dicirikan oleh penduduk yang padat, lalu lintas padat, pusat industri, perdagangan dan pelabuhan, sehingga perairan pesisir Tanjung Balai mempunyai peluang besar tercemar limbah yang mengandung logam berat timbal. Melihat kandungan logam berat yang sudah melebihi ambang batas yang diperkenankan, pemerintah Kota Medan dan Tanjung Balai harus melakukan tindakan yang serius dalam pengendalian pencemaran logam berat timbal tersebut melalui implementasi UU No. 23/1997 tentang Pengelolaan Lingkungan Hidup, dan penerapan Baku Mutu Lingkungan secara lebih ketat. Perlu mendapat perhatian bahwa, logam berat timbal dapat masuk ke tubuh manusia melalui rantai makanan yang bersumber dari laut dan dapat menimbulkan dampak yang sangat berbahaya terhadap kesehatan manusia ${ }^{(14)}$.

Lebih lanjut dikemukakan bahwa, logam berat timbal yang dikenal sangat beracun, bersifat bioakumulatif dalam tubuh organisme air, dan akan terus diakumulasi hingga organisme tersebut tidak mampu lagi mentolerir kandungan logam berat timbal dalam tubuhnya. Dengan sifat bioakumulatif logam berat timbal tersebut, maka bisa terjadi logam tersebut dalam sedimen semakin meningkat konsentrasinya akibat proses-proses fisika, kimia dan biologi perairan, dan dalam tubuh hewan air meningkat sampai beberapa kali lipat (biomagnification $)^{(15,17,18)}$.

Selanjutya dengan sifat toksisitas logam berat timbal yang sangat tinggi dan terakumulasi sampai beberapa kali lipat (biomagnification), maka logam berat ini dikelompokkan menjadi Bahan Berbahaya dan Beracun (B-3) yang pengendaliannnya diatur secara khsusus dalam peraturan pemerintah dengan Baku Mutu yang lebih ketat. Kadar logam berat timbal yang diperbolehkan dalam air untuk kehidupan biota air maksimum 0.03 ppm, dalam air minum maksimum $0.01 \mathrm{ppm}$, dan dalam tubuh ikan maksimum $0.02 \mathrm{ppm}^{(16,17,18)}$. 
Logam berat lain adalah seng (Zn) sebagai zat mineral yang diperlukan oleh tubuh. Kekurangan mineral seng dapat menimbulkan gejala kehilangan selera makan,indra perasa dan penciuman berkurang, penyembuhan luka yang lama, bahkan bisa cacat bayi pada ibu hamil. Sementara itu jika kelebihan mineral seng dapat menyebabkan gejala kram perut, iritasi kulit, mual, muntah, anemia. Tabel-2 menunjukkan bahwa pada saat penelitian dilakukan kandungan $\mathrm{Zn}$ di semua TPS perairan pesisir Kota Lhokseumawe - Kab. Aceh Utara adalah $<0,04$ $\mathrm{mg} / \mathrm{l}$. Nilai konsentrasi ini lebih tinggi daripada pengukuran sebelumnya; dimana seng pada Mei $2015^{(6)}$ disemua TPS $<0,02 \mathrm{mg} / \mathrm{l}$ dan Februari 2016 yang berkisar antara $<0,0083-$ $0,0197 \mathrm{mg} / \mathrm{l}$. Meskipun ditemukan perbedaan konsentrasi, namun semua konsentrasi tersebut masih berada di bawah baku mutu yang berlaku, sehingga berdasarkan seng ditemukan, pesisir Kota Lhokseumawe - Kab. Aceh Utara masih aman untuk semua peruntukan. Hasil kajian ini bukan hanya lebih tinggi dari hasil pengukran sebelumnya, namun juga lebih tinggi daripada konsentrasi seng di pantai Ancol yang dilaporkan hanya $0,0046 \mathrm{mg} / /^{(9,19)}$.

\section{KESIMPULAN}

Mencermati pembahasan tersebut diatas maka dapat disimpulkan bahwa pada saat penelitian ini dilakukan; secara umum kualitas perairan pesisir Kota Lhokseumawe - Kab. Aceh tidak dalam keadaan baik, karena ditemukan parameter timbal $(\mathrm{Pb})$ yang melebihi nilai baku mutu yang berlaku Kepmen-LH 51 Tahun 2004 tentang Baku Mutu Air Laut pada semua peruntukan.

\section{PERSANTUNAN}

Ucapan terima kasih disampaikan pertama, kepada Direktur PTL-BPPT yang telah menugaskan Penulis dalam evaluasi lingkungan di rencana tapak KEK Arun Lhokseumawe. Kedua, ucapan terima kasih disampaikan kepada pihak Instansi terkait di lingkup Provinsi Aceh, dan beberapa pihak yang telah membantu kelancaran kegiatan lapang dan penulisan naskah ini.

\section{DAFTAR PUSTAKA}

1. Anonimus, (2017), Peraturan Pemerintah No.5 Tahun 2017, tentang Kawasan EKonomi Khusus Arun Lhokseumawe

2. Anonimus, (2015), Master Plan Kawasan Ekonomi Khusus (KEK) Arun- Lhoseumawe.

3. Coombs, T.L, (1980,) Animals and Environmental Fitness Volume I
4. Rai, L.L., J. Gaur and H.D. Kumar., (1981), Phycology and Heavy Metal Pollution. In Biological Review of The Phycology Society. Cambridge University Press London.

5. APHA, (1985), Standart Method for the examination of water and waste water, $16^{\text {th }}$ Ed. Washinton D.C.

6. Anonimus, (2015), Laporan Audit Lingkungan PT ARUN.

7. Anonimus, (2016), Laporan Audit Lingkungan PT ARUN.

8. Anonimus, (2004), Kepmen-LH 51 Tahun 2004 tentang Baku Mutu Air Laut.

9. Lestari dan Edward, (2004), Dampak Pencemaran Logam Berat Terhadap Kualitas Air Laut Dan Sumberdaya Perikanan (Studi Kasus Kematian Massal Ikan-Ikan Di Teluk Jakarta), Makara, Sains, Vol. 8, No. 2, 52-58

10. Anon., (2004), Environemntal Watch, Catatan Peristiwa Kerusakan Lingkungan, Forum Pengendali Lingkungan Hidup Indonesia, Jakarta, 2004.

11. Bryan, G.W., (1976), In: A.P.M. Lockwood (Ed.) Effects of pollutants on Aquatic Organisms, Cambridge University Press, Cambridge, 1976.

12. Thamzil, L., S. Suwirna, dan S. Surtipanti, (1980), Majalah Batan XIIII (1980) Nomor:41.

13. Palar, H., (1994), Pencemaran \& Toksikologi Logam Berat, Penerbit Rineka Cipta, Jakarta

14. Sitorus, H., (2004), Analisis Beberapa Karakteristik Lingkungan Perairan Yang Mempengaruhi Akumulasi Logam Berat Timbal Dalam Tubuh Kerang Darah Di Perairan Pesisir Timur Sumatera Utara, Jurnal IImu-ilmu Perairan dan Perikanan Indonesia, Juni 2004, Jilid 11, Nomor 1: 5360

15. Connell, D. W., and G. J. Miller. (1995), Kimia dan Eko- toksikologi Pencemaran. Terjemahan. Penerbit UI Press, Jakarta.

16. Fergusson, J. E. (1990), The Heavy Elements: Chemistry, Environmental Impact and Health Effect. Perga- mon Press, New York.

17. Fadhil, R., Z.A. Muchlisin, dan W. Sari, (2016), Hubungan Panjang-Berat dan Morfometrik Ikan Julung-julung (Zenarchopterus dispar) dari Perairan Pantai Utara Aceh, Jurnal IImiah Mahasiswa 
Kelautan dan Perikanan Unsyiah Volume 1, Nomor 1: 146-159, Januari - April 2016

18. Emersida, I., Sukendi, dan B. Amin, (2014), Kandungan Logam Berat Pada Air dan Tiram (Crassostrea Cucullata Born) di Muara Sungai Loskala Kota Lhokseumawe Provinsi Aceh, Berkala Perikanan Terubuk, Februari 2014, Vol. 42. No.1 Hal: 69 -79, ISSN 0126 - 4265
19. Permanawati, Y., R. Zuraida, Dan A. Ibrahim, (2013), Kandungan Logam Berat ( $\mathrm{Cu}, \mathrm{Pb}, \mathrm{Zn}, \mathrm{Cd}$, Dan $\mathrm{Cr}$ ) dalam Air dan Sedimen di Perairan Teluk Jakarta, Jurnal Geologi Kelautan Volume 11, No. 1, Hal:916, April 2013 